\title{
Menekan Perkawinan Anak Melalui Keberpihakan Akses Perempuan di Indonesia
}

\author{
Kartika Purwaningtyas ${ }^{1}$ \\ Universitas Katolik Parahyangan, Bandung
}

\begin{abstract}
Child marriage in Indonesia is the highest in the world. According to the Central Bureau of Statistics recorded 1.220 .990 girls in Indonesia were married before 18. This article uses literature research to describe the impact of child marriage and policymakers' strategic steps and efforts to curb the high rate of child marriage in Indonesia. Early marriage leads to a vicious cycle of low educational attainment, domestic violence, health, maternal and child health, high maternal mortality, and poverty. As marriage ages, regulation has been changing as a strategy to reduce child marriage. Unfortunately, there is no specific regulation of the marriage dispensation, which creates a gap in the number of weddings and the regulatory aspects of strategic efforts, providing women with immediate access to education, health, and work. Ensuring fair and equitable access between men and women is carried out to the maximum extent from a gender perspective in development policies strategies in Indonesia
\end{abstract}

Keywords : Gender, Human Rights, Child Marriages, Inequality

\begin{abstract}
Abstrak
Perkawinan anak di Indonesia merupakan salah satu yang tertinggi di dunia. Badan Pusat Statistik mencatat sebanyak 1.220 .900 anak perempuan di Indonesia menikah dibawah usia 18 tahun. Melalui studi pustaka dalam artikel ini menggambarkan dampak perkawinan anak dan langkah serta upaya strategis pemangku kebijakan untuk menekan tingginya perkawinan anak di Indonesia. Perkawinan anak mengakibatkan tingkat pendidikan rendah, kekerasan dalam rumah tangga, tingkat kesehatan khususnya ibu dan anak, tingginya angka kematian ibu dan anak serta lingkar kemiskinan. Dengan perubahan kebijakan usia perkawinan di Indonesia sebagai langkah strategis untuk mengurangi tingkat perkawinan anak. Namun sayangnya belum adanya aturan khusus terkait dispensasi pernikahan menjadi celah terhadap tingginya angka perkawinan. Selain sisi regulasi upaya strategis dengan pemberian akses dasar konkret kepada perempuan dalam bidang pendidikan, kesehatan dan tenaga kerja. Pemberian akses secara adil dan merata antara perempuan dan laki - laki dilakukan dengan maksimal dengan implementasi Pengarusutamaan Gender yang baik dalam menentukan kebijakan pembangunan.
\end{abstract}

Kata Kunci : Gender, Hak Asasi Manusia, Perkawinan Anak, Ketimpangan

\footnotetext{
11astatika@ymail.com
} 


\section{Pendahuluan}

Salah satu dari 17 tujuan global untuk mencapai pembangunan yang lebih baik dan berkelanjutan di tahun 2030 adalah menciptakan kesetaraan gender dan pemberdayaan kepada perempuan dan anak perempuan. Cita - cita yang disepakati bersama oleh 193 negara di dunia menjadi rencana aksi yang bersifat universal yang mana tidak ada satupun negara yang tidak berkewajiban menyepakati tujuan pembangunan berkelanjutan. Setelah hampir enam tahun berjalan, tantangan terhadap isu kesetaraan gender masih menjadi pekerjaan rumah khususnya di negara-negara di Benua Asia. Sebagai contohnya negara di kawasan Asia selatan ketimpangan gender disebabkan oleh keyakinan yang menimbulkan nilai patriarki yang berimplikasi terhadap pembentukan norma sosial masyarakat, pengelompokan struktur sosial, agama dan etnis yang mengakibatkan diskriminasi terhadap perkembangan antara perempuan dan laki - laki ${ }^{2}$. Pemahaman bahwa laki - laki dan perempuan tidak memiliki akses terhadap hak asasi manusia yang setara menimbulkan berbagai persoalan sosial dalam masyarakat seperti kemiskinan, rendahnya pendidikan dan kesehatan dan tidak adanya akses atas manfaat pembangunan khususnya bagi perempuan.

Kondisi yang nyata yang berasosiasi akibat ketimpangan gender dengan masih tingginya angka perkawinan anak di Asia. Parahnya angka perkawinan anak di Asia mengalami peningkatan dimana 1 dari 1000 anak di Asia dipaksa untuk menikah akibat kesulitan ekonomi dampak Pandemi Covid-19³. Perkawinan anak sebagai salah satu cara paling cepat agar keluarga miskin tidak terbebani terhadap kebutuhan pemenuhan kebutuhan pokok anak - anaknya. Pendidikan yang rendah dan faktor ketidakamanan secara sosial menjadi salah satu penyebabnya. Perkawinan anak dibawah usia 18 tahun menjadi hal yang umum di India, Indonesia, Vietnam dan Pakistan. Indonesia menjadi negara dengan tingkat

2 UNICEF, "Gender Equality," last modified 2017, accessed July 3, 2021, https://www.unicef.org/rosa/what-we-do/gender-equality.

${ }^{3}$ Haeril Halim and Tran Thi Minh Aishwarya Kumar, "Virus Despair Forces Girls across Asia into Child Marriage," last modified 2020, accessed July 3, 2021, https://www.thejakartapost.com/news/2020/09/01/virus-despair-forces-girls-across-asia-into-childmarriage.html. 
Perkawinan anak tinggi di dunia. Berdasarkan data Susenas Badan Pusat Statistik di Tahun 2018, 1 dari 9 perempuan di Indonesia pada rentang usia 20 - 24 tahun telah menikah sebelum usia 18 tahun. Statistik mencatat sebanyak 1.220 .900 anak perempuan di Indonesia menikah dibawah usia 18 tahun. Dampak yang ditimbulkan akibat perkawinan anak diantaranya dengan tingginya angka kematian bayi sebelum berusia 28 hari yang dilahirkan ibu dengan usia 20 - 29 tahun, rentan terhadap kekerasan dalam rumah tangga dan buruknya kondisi kesehatan kandungan ibu 4 .

Menyikapi persoalan pernikahan anak di Indonesia, Pemerintah telah melakukan upaya dengan menerbitkan Undang - Undang Nomor 16 Tahun 2019 tentang Perubahan Undang - Undang 1 Tahun 1974 tentang Perkawinan yang melakukan revisi terhadap batas usia menikah bagi perempuan menjadi 19 tahun dan mengatur ulang terhadap klausul dispensasi pernikahan bagi Pengadilan Agama terhadap penetapan perkawinan anak dibawah umur. Perubahan terhadap regulasi pernikahan yang diharapkan mampu menekankan angka perkawinan anak tidak efektif. Faktanya Badan Peradilan Agama mencatat sebanyak 64,2 ribu dispensasi perkawinan anak pada tahun 2020 atau meningkat hampir tiga kali lipat dibandingkan tahun 2019 yang hanya sebesar 23,1 ribu dispensasi ${ }^{5}$. Pernikahan anak mengakibatkan dampak sosial, ekonomi, sosial, kesehatan dan budaya ${ }^{6}$. Lebih lanjut bahwa faktor dominan yang mengakibatkan pernikahan anak yaitu kurangnya pendidikan dan tingkat ekonomi masyarakat ${ }^{7}$. Studi yang dilakukan di Indonesia menggambarkan bahwa pernikahan anak bagi anak perempuan tiga kali dibandingkan anak laki - laki. ${ }^{8}$ Perkawinan anak menjadi salah satu opsi yang

\footnotetext{
${ }^{4}$ Badan Pusat Statistik, Child Marriage in Indonesia, 2020.

5 Komnas Perempuan, “Perempuan Dalam Himpitan Pandemi : Lonjakan Kekerasan Seksual,Kekerasan Siber,Perkawinan Anak,Dan Keterbatasan Penanganan Ditengah Covid-19,"

${ }^{6}$ Ana Latifatul Muntamah, Dian Latifiani, and Ridwan Arifin, "Pernikahan Dini Di Indonesia: Faktor Dan Peran Pemerintah (Perspektif Penegakan Dan Perlindungan Hukum Bagi Anak)," Widya Yuridika 2, no. 1 (2019): 1; Reni Djamilah; Kartikawati, "Dampak Perkawinan Anak Di Indonesia," Jurnal Studi Pemuda 3, no. 1 (2014): 1-16.

7 Djamilah; Kartikawati, "Dampak Perkawinan Anak Di Indonesia."

${ }^{8}$ Eka Yuli Handayani, "Faktor-Faktor Yang Berhubungan Dengan Pernikahan Usia Dini Pada Remaja Putri Di Kecamatan Tambusai Utara Kabupaten Rokan Hulu," Faktor-Faktor Yang Berhubungan Dengan Pernikahan Usia Dini Pada Remaja Putri Di Kecamatan Tambusai Utara Kabupaten Rokan Hulu (2014).
} 
diharapakan mampu mengurangi persoalan ekonomi dan kesejahteraan dan berkorelasi kuat dengan kondisi bencana alam yang dihadapi oleh masyarakat ${ }^{9}$. Maraknya perkawinan anak menjadi alarm penting bahwa ada indikasi kemunduran pencapaian kesetaraan gender dan penegakan Hak Asasi Manusia (HAM) di Indonesia. Tingginya perkawinan anak di Indonesia selama kurun waktu dua tahun terakhir perlu dilakukan telaah secara komprehensif. Melalui studi pustaka dan telaah data sekunder, artikel ini bertujuan untuk menggambarkan secara deskriptif terhadap dampak perkawinan anak dan langkah serta upaya strategis pemangku kebijakan untuk menekan tingginya perkawinan anak di Indonesia.

\section{Metode Penelitian}

Analisa dalam pembahasan mengenai persoalan perkawinan anak dan upaya penanggulangannya dalam kerangka Kebijakan Indonesia menggunakan pendekatan deskriptif yang akan mengurai secara logis dan komprehensid dari sumbersekunder diantaranya artikel ilmiah, dokumen laporan tahunan dan berbagai pustaka yang terkait persoalan yang dibahas ${ }^{10}$. Untuk mengkaji isu mengenai perkawinan anak dan bagaimana langkah serta upaya strategis stakeholders untuk mengatasi persoalan dilakukan melalui artikel ilmiah isu gender, Laporan Kementerian Kesehatan Republik Indonesia dan Media pemberitaan cetak maupun online yang digunakan sebagai sumber utama terhadap kajian yang dipaparakan dalam artikel ini.

\footnotetext{
${ }^{9}$ Luh Putu Ratih Kumala Dewi and Teguh Dartanto, "Natural Disasters and Girls Vulnerability: Is Child Marriage a Coping Strategy of Economic Shocks in Indonesia?," Vulnerable Children and Youth Studies 14, no. 1 (2019): 24-35, https://doi.org/10.1080/17450128.2018.1546025.

10 Bert Van Wee and David Banister, "How to Write a Literature Review Paper?," Transport Reviews 36, no. 2 (2016): 278-288; Hannah Snyder, "Literature Review as a Research Methodology: An Overview and Guidelines," Journal of Business Research 104, no. July (2019): 333-339, https://doi.org/10.1016/j.jbusres.2019.07.039.
} 


\section{Hasil dan Pembahasan}

\section{Kesetaraan Gender bagian dalam pemenuhan Hak Asasi Manusia}

Hak asasi manusia sebagai sesuatu yang melekat kepada individu tanpa terkecuali dimana tidak memperhatikan ras, suku, bahasa, agama, status sosial dan aspek lainnya. Hak Asasi Manusia bersifat universal yang mana seorang individu bebas untuk mendapatkan segala hak sebagai seorang manusia yang merdeka dan terbebas dari berbagai tindakan seperti perbudakan, penyiksaan, pengekangan terhadap hak berpendapat dan berekspresi serta tidak memperoleh pendidikan yang layak, kesehatan yang berkualitas dan menghidupi kehidupan secara layak. Persatuan Bangsa - Bangsa (PBB) telah mendeklarasikan tentang Hak Asasi Manusia (Universal Declaration Human Rights) pada tahun 1948 yang pada pokoknya bahwa semua orang dilahirkan merdeka dan mempunyai martabat dan hak-hak yang sama. Pernyataan PBB dapat diartikan bahwa laki - laki dan perempuan memiliki hak dan kesempatan yang sama sebagai individu yang merdeka.

Fakta kesempatan dan hak yang diperoleh antara laki - laki dan perempuan tidaklah sama sehingga mengakibatkan adanya gap yang salah satunya adanya konstruksi sosial, agama dan budaya. Konstruksi terhadap perempuan dan laki laki menjadi kelompok yang tidak sama dan memiliki hak serta kesempatan yang berbeda mengakibatkan ketimpangan gender. Perempuan dianggap sebagai kelompok lemah yang dalam perannya berfokus pada urusan domestik sehingga kesempatan untuk memperoleh pendidikan yang setara dengan laki - laki, karir dan keterwakilan dalam berbagai sektor dianggap sebagai sesuatu yang menyalahi konstruksi sosial. Sedangkan laki - laki dianggap sebagai kelompok superior yang memiliki kuasa tanpa batas dalam mengakses berbagai hak dan kesempatan sosial seperti dalam bidang tenaga kerja, pendidikan dan politik. Perbedaan akses atas hak antara perempuan dan laki - laki ini menekankan para pemangku kepentingan untuk mendorong kesetaraan gender. Kesetaraan gender menyiratkan bahwa kepentingan, kebutuhan dan prioritas perempuan dan laki - laki dipertimbangkan dengan mengakui keragaman dari dua kelompok ini sehingga memiliki kesempatan yang 
adil yang berdampak terhadap pemenuhan hak asasi manusia ${ }^{11}$. Stigma dilekatkan kepada perempuan dianggap tidak mampu mandiri secara ekonomi, rendahnya akses terhadap pelayanan publik dasar seperti kesehatan dan pendidikan yang berkualitas, tidak diberikan posisi dan peran strategis dalam peran pengambil kebijakan sehingga mengakibatkan adanya gap antara perempuan dan laki - laki dalam berbagai aspek strategis. Kesetaraan gender menjadi penting untuk dapat diimplementasikan dalam berbagai aspek kesehatan. Bahwa Mencapai kesetaraan antara perempuan dan laki - laki dan menghapus segala bentuk diskriminasi terhadap perempuan merupakan bagian dalam hak asasi manusia dan nilai dasar persatuan bangsa - bangsa. ${ }^{12}$ Untuk mencapai kesetaraan antara perempuan dan laki - laki memerlukan pemahaman yang menyeluruh sehingga dapat memformulasikan cara strategis mengurangi diskriminasi terhadap perempuan sehingga pemenuhan hak asasi manusia dapat terwujud.

\section{Pengarusutamaan Gender dalam Kebijakan Publik sebagai Perwujudan Hak}

\section{Asasi Manusia}

Diskriminasi yang dihadapi oleh perempuan mengancam kebebasan sebagai seorang individu yang Mereka. Pembiaran terhadap tindakan diskriminasi yang berimbas terhadap berbagai tindakan pelecehan, kekerasan dan penindasan yang dihadapi oleh perempuan. Memastikan hak perempuan terimplementasi dengan maksimal dengan adil menjadi bagian dalam pemenuhan hak asasi manusia. Diperlukan pemahaman secara komprehensif tentang bagaimana hubungan dalam struktur sosial dan hubungan kekuasaan yang mampu menentukan dan mempengaruhi perempuan untuk menikmati hak-nya. Bahwa penegakan kesetaraan gender dalam struktur sosial tidak dapat maksimal tanpa didorong dengan dukungan pada sisi kebijakan yang berimplikasi terhadap berbagai pengaturan segala aspek hak perempuan dan laki- laki secara normatif melalui strategi pengarusutamaan

\footnotetext{
${ }^{11}$ Vibhuti Patel, "Gender Equality and Human Rights.," Gender Equality and Human Rights in India 1, no. 28 (2011): 1-3; Jonathan Woetzel et al., The Power of Parity: How Advancing Women's Equality Can Add \$12 Trillion to Global Growth, McKinsey Global Institute, 2015.

12 United Nations, "Transforming Our World : The 2030 Agenda For Sustainable Development"

(2015): 12-14.
} 
gender (gender mainstreaming). Pengarusutamaan gender (PUG) merupakan proses demokratisasi gender salah satunya berbagai pertimbangan perempuan dari persepsi terhadap kepentingan dalam pembangunan. ${ }^{13}$ PUG sebagai bagian dalam strategi pembangunan digunakan untuk mencapai kesetaraan dan keadilan gender dimana proses pengintegrasian terhadap berbagai pengalaman, aspirasi, kebutuhan dan permasalahan perempuan dan laki - laki ke dalam seluruh tahapan kebijakan di berbagai bidang kehidupan dan pembangunan. ${ }^{14}$

Pendekatan pengarusutamaan gender dalam kebijakan memberikan perhatian khusus kepada kelompok yang mengalami marginalisasi atas dampak yang ditimbulkan dari bias gender, maka perlu memastikan bahwa perempuan dan laki - laki memiliki akses partisipasi dan kontrol yang sama. ${ }^{15}$ Kunci dalam pengarusutamaan gender bahwa akses yang diperoleh perempuan dan laki - laki sama dan adil dalam berbagai aspek pembangunan sehingga kesenjangan gender dapat ditekan dengan maksimal. Kebijakan yang diformulasikan dengan pendekatan pengarusutamaan gender akan mempertimbangkan hambatan dan kemampuan terhadap mengakses hasil pembangunan. Melalui pengarusutamaan gender berbagai kebutuhan praktis gender khususnya perempuan dapat dengan baik terimplementasi dalam merespon berbagai kebutuhan jangka pendek maupun jangka panjang. Lebih lanjut PUG menjadi standar keadilan baru dimana dapat menggantikan standar yang masih berorientasi pada pemenuhan hak laki - laki secara optimal dibandingkan dengan pemenuhan setara kepada perempuan bagi individu untuk menggantikan standar yang berorientasi kepada laki - laki dari kebijakan bagi perempuan dan laki - laki. $^{16}$

\footnotetext{
${ }^{13}$ Sylvia Walby, "Gender Mainstreaming: Productive Tensions in Theory and Practice," Social Politics 12, no. 3 (2005): 321-343; Tri Yumarni and Dilanthi Amaratunga, "Gender Mainstreaming and Sustainable Development Goals: A Systematic Literature Review in Post Disaster Reconstruction Area," in MATEC Web of Conferences, 2018.

${ }^{14}$ W. K. Rahayu, "Analisis Pengarusutamaan Gender Dalam Kebijakan Publik (Studi Kasus Di BP3AKB Provinsi Jawa Tengah)," JAKPP (Jurnal Analisis Kebijakan \& Pelayanan Publik) (2017).

${ }^{15}$ Instruksi Presiden Nomor 9 Tahun 2000 tentang Pengarusutamaan Gender (PUG)

16 Shirin M. Kai, Mainstreaming Gender, Democratizing the State, Mainstreaming Gender, Democratizing the State, 2017; Walby, "Gender Mainstreaming: Productive Tensions in Theory and Practice."
} 
Kebijakan yang disusun oleh pemangku kepentingan harus mempertimbangkan akses kebutuhan dasar kelompok rentan sepanjang hayat dari individu khususnya perempuan seperti pendidikan, kesehatan, penyediaan air bersih, lapangan kerja layak, partisipasi politik yang seimbang dan aspek lainnya berkaitan dengan perbaikan taraf hidupnya. Mengimplementasikan Pengarustamaan Gender dalam kebijakan berbanding lurus dengan pemenuhan hak asasi manusia.

\section{Hasil dan Pembahasan}

Perkawinan Anak dan Ketimpangan Gender di Indonesia : Sebuah Telaah Mengenai Dampak Yang Ditimbulkan Terhadap Perempuan

Konvensi Hak Anak (Convention on the Rights of the Child) mendefinisikan perkawinan anak sebagai perkawinan yang terjadi untuk individu dengan usia dibawah 18 tahun. Berbanding terbalik dengan Indonesia dalam ketentuan Undang - Undang Nomor 1 Tahun 1978 tentang Perkawinan menyatakan bahwa perkawinan hanya diizinkan jika pihak pria mencapai usia 19 (sembilan belas) tahun dan pihak wanita sudah mencapai 16 (enam belas). Diatur lebih jauh dalam regulasi perkawinan di Indonesia bahwa dalam hal adanya penyimpangan dalam ketentuan usia perkawinan dapat meminta Dispensasi kepada pengadilan atau Pejabat lain yang ditunjuk oleh kedua orang tua pihak pria maupun pihak wanita. Kondisi ini semakin menguatkan bahwa perkawinan anak tidak dapat dihindarkan di Indonesia. Bahwa tren perkawinan anak perempuan di Indonesia dapat dikatakan masih tinggi tercatat secara nasional berdasarkan persentase perempuan usia 20 24 tahun menurut usia perkawinan pertama kurang dari 18 tahun pada tahun 2018 mencapai 16,87 persen. Bahwa angka ini mengalami penurunan sebesar 3,5 persen dari tahun 2017. 
Tabel 1. Tren Data Persentase Perempuan Usia 20 -24 Tahun menurut Usia Perkawinan Pertama Tahun 2014 - 2018

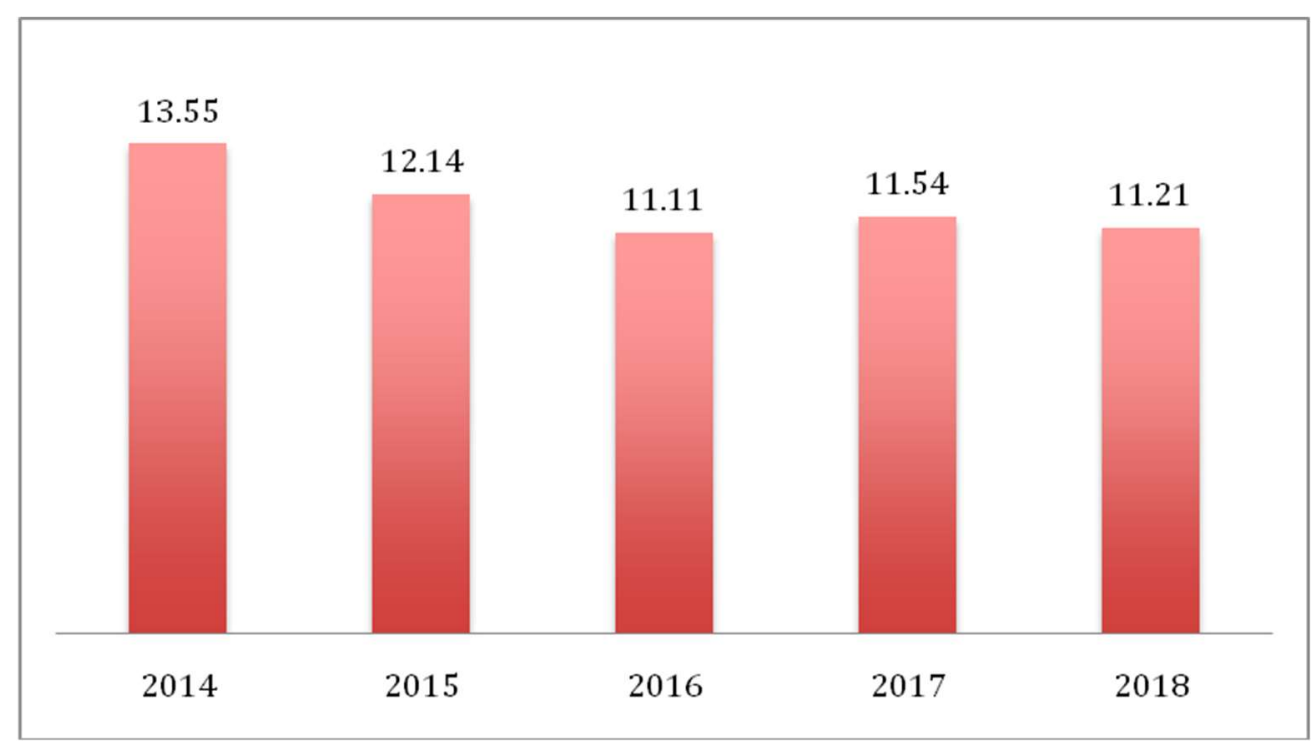

Sumber : Profil Anak Indonesia, 2020

Tingginya tren perkawinan anak ini menimbulkan berbagai dampak signifikan dan bagian dalam pelanggaran hak asasi manusia karena tidak memberikan kesempatan seluas - luasnya khususnya perempuan untuk mengakses kesempatan pendidikan, kesehatan dan keamanan sebagai seorang anak yang dilindungi oleh Undang - undang. Perempuan yang menikah dibawah usia beresiko mengalami berbagai tindakan kekerasan dan penindasan yang dialami dalam rumah tangga, kehamilan remaja, peningkatan risiko kematian dan cedera ibu dan bayi yang baru lahir. Dalam bidang pendidikan, pengantin anak tidak memiliki kesempatan untuk melanjut pada jenjang lanjutan bahkan cenderung hilang. Bahwa pada pernikahan sebelum usia 18 tahun mengakibatkan pengurangan kemungkinan penyelesaian sekolah menengah sebesar 6 persen $^{17}$.

\footnotetext{
${ }^{17}$ Badan Pusat Statistik, Laporan Profil Anak, 2020.
} 
Tabel. 2 Rata - Rata Lama Berdasarkan Tahun Penduduk Usia 20 - 24 Tahun dan Usia Perkawinan Pertama Tahun 2018

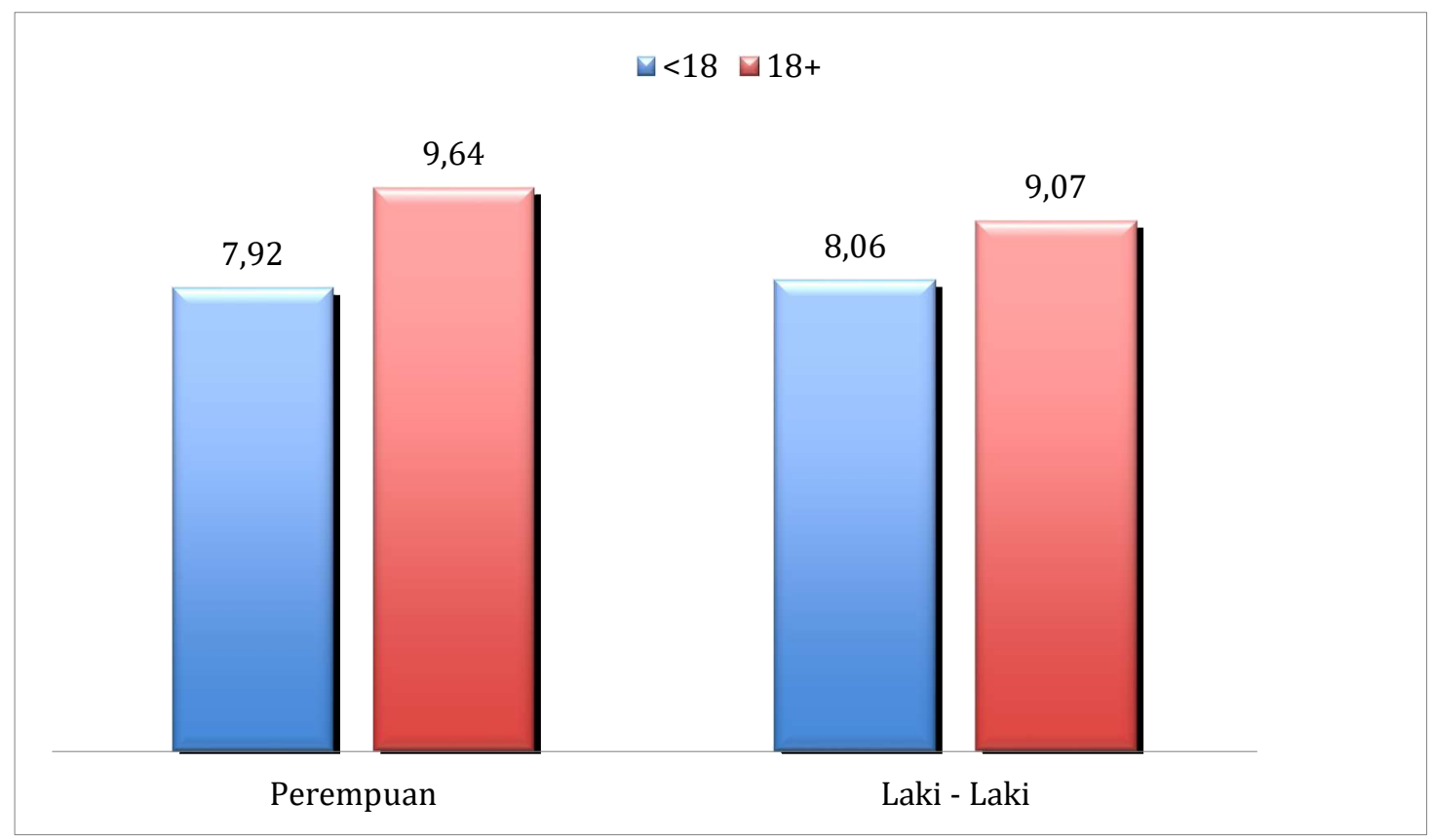

Sumber : Survei Sosial Ekonomi Nasional, 2018

Berdasarkan data Survei Sosial Ekonomi Nasional Tahun 2018, rata-rata lama sekolah baik pada laki-laki maupun perempuan yang menikah sebelum usia 18 tahun lebih rendah dibanding yang menikah lebih dari 18 tahun. Pernikahan anak menurunkan angka partisipasi sekolah khususnya pada Perempuan di jenjang pendidikan menengah. Sebaliknya dengan melakukan penundaan pernikahan anak selama satu tahun dapat meningkatkan angka partisipasi pendidikan dan penuntasan sekolah. ${ }^{18}$

\footnotetext{
${ }^{18}$ Colleen Murray Gastón, Christina Misunas, and Claudia Cappa, “Child Marriage among Boys: A Global Overview of Available Data," Vulnerable Children and Youth Studies (2019); Marcos Delprato and Kwame Akyeampong, "The Effect of Early Marriage Timing on Women's and Children's Health in Sub-Saharan Africa and Southwest Asia," Annals of Global Health (2017); Endah Ratnawaty Chotim, "A Perspective towards the Praxis of Child Marriage in Indonesia," International Journal of Innovation, Creativity and Change. (2019).
} 
Resiko lainnya yang dihadapi perempuan akibat perkawinan dibawah umur adalah tingginya angka kematian ibu yang diakibatkan rendahnya kualitas kesehatan ibu. Selama 1991 - 2015 angka kematian ibu mengalami penurunan dari 390 menjadi 305 per 100.000 kelahiran hidup ${ }^{19}$. Angka ini masih dikategorikan tinggi dibandingkan dengan target Pemerintah Indonesia diharapkan turun menjadi 131 per 100.000 kelahiran hidup. Penurunan angka kematian ibu berkorelasi erat dengan jaminan terhadap akses kesehatan dan kualitas pelayanan kesehatan hulu ke hilir. Sulitnya akses kesehatan oleh Perempuan seperti tempat bersalin menjadi penyebab tingginya angka kematian ibu karena tidak mendapatkan pertolongan segera oleh petugas kesehatan. Riset Kesehatan Dasar Kementerian Kesehatan pada 2018 mencatat bahwa penggunaan rumah sebagai tempat bersalin masih cukup tinggi sebanyak 16,7 persen dan 62,5 rumah tangga menyatakan bahwa 62,5\% rumah tangga menyatakan akses ke rumah sakit sulit ${ }^{20}$.

Sulitnya akses kesehatan perempuan melalui pelayanan kesehatan buruk baik sarana maupun tenaga kesehatan menunjukan bahwa pemenuhan hak asasi manusia yang rendah. Selain rendahnya akses pelayanan pendidikan dan kesehatan, perempuan menghadapi berbagai tindakan kekerasan Komnas Perlindungan Perempuan dan Anak mencatat angka kekerasan terhadap istri (KTI) sepanjang tahun 2020 menempati peringkat pertama sebanyak 6.555 kasus (59\%) dan kekerasan terhadap anak perempuan sebanyak 2.341 kasus (21\%). Angka ini terus mengalami peningkatan setiap tahunnya salah satu penyebabnya adalah rendahnya tingkat kesejahteraan rumah tangga. Kesejahteraan rumah tangga yang menjadi faktor penyebab utama kekerasan dari rumah tangga salah satunya terjadi pada rumah tangga yang dibangun sebelum usia pasangan kurang dari 18 tahun. Badan Pusat Statistik dalam Susenas 2018 mencatat bahwa sebanyak 26,76 persen Perempuan Usia 20 - 24 yang melakukan perkawinan sebelum 18 tahun masuk dalam kategori kelompok dengan tingkat kesejahteraan rendah ${ }^{21}$.

\footnotetext{
${ }^{19}$ Badan Pusat Statistik, Profil Kesehatan Indonesia, 2019.

${ }^{20}$ Badan Pusat Statistik, Riset Kesehatan Dasar, 2018.

${ }^{21}$ UNICEF Indonesia, Statistic Indonesia (BPS) PUSKAPA UI, and Kementerian PPN/ Bappenas, "Child Marriage in Indonesia Latest Statistics of Child Marriage in Indonesia," Badan Pusat Statistik (2020).
} 
Perkawinan anak berdampak terhadap peningkatan ekonomi karena perempuan tidak cukup produktif untuk mengakses sumber pendapatan karena beban ganda dan rendahnya tingkat pendidikan. Dalam aspek tenaga kerja perempuan tidak diberikan akses dan pembatasan terhadap kontribusi dalam berbagai sektor lapangan pekerjaan dibandingkan laki - laki. Tingkat Partisipasi angkatan kerja perempuan (51,88\%) lebih rendah dibandingkan laki - laki $(82,69 \%)$. Selain dalam angka partisipasi angkatan kerja, ketimpangan gender terjadi dalam aspek upah dimana laki - laki memiliki upah yang lebih tinggi dibanding perempuan ${ }^{22}$. Ketiadaan akses pekerjaan dan upah yang layak perempuan diperparah dengan dominasi perempuan sebanyak $61,80 \%$ bekerja di sektor informal. Angka ini lebih tinggi dibandingkan laki - laki yang didominasi dalam posisi di sektor formal. Bahwa perkawinan anak dan ketimpangan gender berkorelasi menimbulkan berbagai dampak negatif terhadap perempuan sehingga perempuan tidak dapat mengakses pemenuhan hak asasi manusia sebagai seorang individu yang merdeka.

\section{Langkah dan Upaya Strategis Menekan Tingkat Perkawinan Anak}

Tingginya perkawinan anak di Indonesia disebabkan salah satunya regulasi pemerintah melalui Undang- Undang Perkawinan yang tidak bersinergi dengan aturan perlindungan anak yang mana menjamin bahwa anak sampai dengan usia 18 tahun termasuk dalam kategori anak sedangkan Undang - Undang Perkawinan mengatur minimal usia anak menikah 16 tahun dan aturan dispensasi bagi perkawinan dibawah usia yang ditentukan oleh Undang - Undang. Hal tersebut menjadi peluang dan menyuburkan praktek perkawinan anak di Indonesia. Pemerintah melakukan revisi undang - undang perkawinan melalui Undang Undang Nomor 16 Tahun 2019 tentang perubahan Undang - Undang Nomor 1 Tahun 1974 tentang Perkawinan yang salah satunya melakukan perubahan terhadap usia minimal perkawinan menjadi 19 tahun bagi perempuan dan laki - laki. Perubahan usia minimal pernikahan menjadi langkah strategis pemerintah untuk

\footnotetext{
${ }^{22}$ Badan Pusat Statistik, Profil Perempuan Indonesia, 2020.
} 
mengurangi tingkat Perkawinan anak. Namun sayangnya Pasal 7 ayat 2 Undang Undang Nomor 16 Tahun 2019 terkait dispensasi pernikahan belum mengatur dengan jelas klasifikasi dan kriteria perkawinan dibawah umur yang diberikan dispensasi. Lebih lanjut kondisi ini dapat memberikan perkawinan anak melalui Pasal Dispensasi tanpa diberikan penekanan terhadap indikator dispensasi perkawinan yang diberikan oleh Pengadilan atau Pejabat yang berwenang. Pemerintah Indonesia melalui Kementerian Pemberdayaan Perempuan dan Perlindungan Anak merumuskan percepatan strategi dalam rangka mencegah perkawinan anak diantaranya melalui penguatan dan sinergi kelembagaan Kementerian/Lembaga/Pemerintah Daerah, penyusunan Rencana Aksi Pencegahan Perkawinan Anak dan Kampanye Stop Perkawinan Anak $^{23}$. Bahwa Upaya pemerintah terhadap kebijakan percepatan pencegahan perkawinan anak masih bersifat normatif sehingga diperlukan upaya strategis agar perkawinan anak dapat dicegah dengan maksimal. Implementasi pengarusutamaan gender melalui berbagai metode salah satunya dengan melakukan analisis gender (Gender Analysis Pathway) sejak tahap perencanaan pembangunan sampai dengan pelaksanaan pembangunan pada setiap level pemerintah dari Desa/kelurahan ke tingkat Nasional menjadi penting. Perumusan kebijakan yang responsif gender memberikan kesempatan terbuka untuk mewujudkan kebijakan yang memahami dan menyelesaikan permasalahan perempuan khususnya terhadap akses - akses dasar yang beresiko adanya ketimpangan.

Secara praktis, pemberian akses perempuan dalam berbagai aspek strategis dengan pelibatan secara aktif perempuan dalam bidang politik melalui kesempatan dan ruang partisipasi perempuan dalam partai politik. Hal ini akan mampu mendorong kebijakan yang merespon isu gender secara masif .termasuk pencegahan perkawinan anak. Lebih lanjut peningkatan akses pendidikan kepada perempuan melalui berbagai program bantuan pendidikan perlu ditingkatkan dimana saat ini pemerintah memfokuskan bantuan pendidikan untuk siswa yang berasal dari

\footnotetext{
23 Perempuan dan Perlindungan Anak Kementerian Pemberdayaan, "KEMEN PPPA TERAPKAN LIMA STRATEGI PENCEGAHAN PERKAWINAN ANAK"; Riska Yunitasari Yunitasari, "Dinamika Pembaharuan Batas Usia Perkawinan (Analisis Batas Umur Melangsungkan Pernikahan Dalam Hukum Nasional Indonesia)," DOKTRINA: JOURNAL OF LAW 3, no. 1 (2020): 9-21.
} 
keluarga miskin melalui Kartu Indonesia Pintar. Hal ini dapat ditingkatkan dengan pemberian bantuan pendidikan sehingga menjamin kesempatan seluas - luasnya kepada anak tanpa terkecuali untuk mengakses pendidikan sejak tingkat pendidikan dasar sampai dengan menengah. Sarana dan prasarana pendidikan menjadi bagian penting untuk meningkatkan kualitas pendidikan, penambahan sekolah dan tenaga kependidikan khususnya di wilayah terpencil dan terluar. Perbaikan kurikulum pendidikan dimana harus responsif gender yang mana secara sistemik membentuk pola dan mindset tentang peran perempuan dan laki - laki menjadi penting. Pemberian akses pendidikan secara komprehensif dapat mengurangi angka perkawinan. ${ }^{24}$ Pendidikan menjadi bagian dalam pemenuhan hak asasi manusia dan mencapai kesetaraan karena dapat meningkatkan kualitas perempuan khususnya seperti dalam hal aspek literasi bagi perempuan ${ }^{25}$.

Akses dasar yang menjadi penting terhadap pelayanan bidang kesehatan diantaranya optimalisasi layanan informasi kesehatan reproduksi secara menyeluruh kepada anak usia dibawah 18 tahun, peningkatan dukungan layanan kesehatan primer tingkat Desa/Kelurahan melalui Posyandu dengan terintegrasi layanan kesehatan pertama dan utama sehingga mampu mencegah kehamilan yang tidak diinginkan yang salah satunya dijadikan alasan perkawinan anak. Selain itu akses terhadap pendampingan anak korban tindakan kekerasan dan pelecehan harus maksimal diupayakan dengan memastikan hak dari korban dalam pengembangan rujukan melalui fasilitas kesehatan tingkat pertama bagi anak yang mengalami korban tindakan yang dimaksud.

Perkawinan anak yang terjadi disebabkan karena lingkaran kemiskinan rumah tangga. Keluarga dengan tingkat kemiskinan ekstrim menganggap bahwa pernikahan anak menjadi cara untuk mengurang ekonomi dan menghindari dari kerawanan pangan. Kemiskinan yang terjadi diakibatkan tidak adanya akses

\footnotetext{
${ }^{24}$ Quentin Wodon et al., "Educating Girls and Ending Child Marriage: A Priority for Africa.," The cost of not educating girls notes series (2018).

${ }^{25}$ Muntamah, Latifiani, and Arifin, "Pernikahan Dini Di Indonesia: Faktor Dan Peran Pemerintah (Perspektif Penegakan Dan Perlindungan Hukum Bagi Anak)"; Michelle Kaffenberger and Lant Pritchett, "Aiming Higher: Learning Profiles and Gender Equality in 10 Low- and Middle-Income Countries," International Journal of Educational Development (2020).
} 
pendapatan rumah tangga. Pemberian akses tenaga kerja secara adil antara perempuan dan laki - laki menjadi salah satu cara memutus tingkat perkawinan anak. Anak perempuan dianggap sebagai kelompok rentan dan tidak berdaya sehingga tidak mampu memberikan kontribusi secara signifikan dibandingkan laki laki. Stigma sosial ini dapat hilang dengan memberikan kesempatan seluas luasnya melalui berbagai sektor lapangan pekerjaan secara rata antara perempuan dan laki - laki. Elaborasi pemangku kepentingan pada sisi regulasi, kelembagaan dan sosial merupakan strategi penting untuk menghasilkan berbagai kebijakan dalam mengakses hak perempuan secara adil.

\section{Kesimpulan}

Perkawinan anak merupakan bagian dalam pelanggaran hak asasi manusia. Perkawinan anak khususnya bagi perempuan akan meningkatkan resiko kekerasan dalam rumah tangga. Masih tingginya praktik perkawinan anak di Indonesia diakibatkan adanya ketimpangan gender yang diakibatkan adanya konstruksi sosial yang mendasari berbagai kebudayaan yang membenarkan perkawinan anak, ketimpangan hasil pembangunan dan ketiadaan pelibatan perempuan dalam pengambilan kebijakan. Dampak lainnya bahwa perkawinan anak mendorong berbagai permasalahan kerentanan kepada perempuan dalam pemenuhan haknya sebagai individu yang bebas. Urgensi implementasi pengarusutamaan gender terhadap berbagai proses pengambilan dan implementasi kebijakan pembangunan mendesak untuk dilakukan. Kebijakan pemerintah Indonesia dengan melakukan revisi Undang - undang Perkawinan tidak dapat secara maksimal memutus perkawinan anak tanpa adanya upaya strategis berbagai pemangku kepentingan untuk memberikan akses dan kesempatan dalam berbagai sektor utama yaitu pendidikan, kesehatan dan tenaga kerja kepada perempuan. Langkah konkret pemberian akses kepada perempuan tidak hanya menjadi kewajiban murni

pemerintah juga diperlukan tapi partisipasi aktif dari masyarakat untuk dapat melakukan upaya pencegahan perkawinan anak. Bahwa pembiaran perkawinan anak berbanding lurus dengan peningkatan kemiskinan di sebuah negara. 


\section{Daftar Pustaka}

Badan Pusat Statistik. 2020. Child Marriage in Indonesia.

-. Laporan Profil Anak, 2020.

_. Profil Kesehatan Indonesia, 2019. . Profil Kesehatan Dasar, 2020

- Profil Perempuan Indonesia, 2020.

- Riset Kesehatan Dasar, 2018.

Chotim, Endah Ratnawaty. 2019. A Perspective towards the Praxis of Child Marriage in Indonesia. International Journal of Innovation, Creativity and Change

Delprato, Marcos and Akyeampong, Kwame. 2017. The Effect of Early Marriage Timing on Women's and Children's Health in Sub-Saharan Africa and Southwest Asia. Annals of Global Health.

Dewi, Luh Putu Ratih Kumala; and Dartanto, Teguh. 2019. Natural Disasters and Girls Vulnerability: Is Child Marriage a Coping Strategy of Economic Shocks in Indonesia?. Vulnerable Children and Youth Studies 14(1):24-35. https://doi.org/10.1080/17450128.2018.1546025.

Djamilah dan Kartikawati, Reni. 2014. Dampak Perkawinan Anak Di Indonesia. Jurnal Studi Pemuda 3(1): 1-16.

Gastón, Colleen Murray; Misunas, Christina; and Cappa, Claudia. 2019. Child Marriage among Boys: A Global Overview of Available Data. Vulnerable Children and Youth Studies

Handayani, Eka Yuli. 2014. Faktor-Faktor Yang Berhubungan Dengan Pernikahan Usia Dini Pada Remaja Putri Di Kecamatan Tambusai Utara Kabupaten Rokan Hulu. Maternity and Neonatal : Jurnal Kebidanan 1(5)

Kaffenberger, Michelle and Pritchett, Lant. 2020. Aiming Higher: Learning Profiles and Gender Equality in 10 Low- and Middle-Income Countries. International Journal of Educational Development.

Kai, Shirin M. 2017. Mainstreaming Gender, Democratizing the State. Mainstreaming Gender. Democratizing the State

Kementerian Pemberdayaan, Perempuan dan Perlindungan Anak. KEMEN PPPA TERAPKAN LIMA STRATEGI PENCEGAHAN PERKAWINAN ANAK.

Komisi Nasional Anti Kekerasan Terhadap Perempuan. 2021. Perempuan Dalam Himpitan Pandemi: Lonjakan Kekerasan Seksual, Kekerasan Siber, Perkawinan Anak, dan Keterbatasan Penanganan Ditengah Covid-19. Catatan Tahunan

Kumar, Aishwarya; Halim, Haeril dan Minh, Tran Thi. Virus Despair Forces Girls Across Asia into Child Marriage. Last modified 2020. Accessed July 3, 
2021. https://www.thejakartapost.com/news/2020/09/01/virus-despairforces-girls-across-asia-into-child-marriage.html.

Muntamah, Ana Latifatul; Latifiani, Dian; and Arifin, Ridwan. 2019. Pernikahan Dini di Indonesia: Faktor Dan Peran Pemerintah (Perspektif Penegakan Dan Perlindungan Hukum Bagi Anak). Widya Yuridika 2(1).

Patel, Vibhuti. 2011. Gender Equality and Human Rights. Gender Equality and Human Rights in India 1. 28: 1-3.

Rahayu, W. K. 2017. Analisis Pengarusutamaan Gender Dalam Kebijakan Publik (Studi Kasus Di BP3AKB Provinsi Jawa Tengah). JAKPP (Jurnal Analisis Kebijakan \& Pelayanan Publik)

Snyder, Hannah. 2019. Literature Review as a Research Methodology: An Overview and Guidelines. Journal of Business Research 104: 333-339. https://doi.org/10.1016/j.jbusres.2019.07.039.

UNICEF Indonesia, Statistic Indonesia (BPS) PUSKAPA UI, and Kementerian PPN/ Bappenas. 2020. Child Marriage in Indonesia Latest Statistics of Child Marriage in Indonesia. Badan Pusat Statistik

UNICEF. 2017. Gender Equality. Accessed July 3, 2021. https://www.unicef.org/rosa/what-we-do/gender-equality.

United Nations. 2015. Transforming Our World: The 2030 Agenda For Sustainable Development. 12-14.

Walby, Sylvia. 2005. Gender Mainstreaming: Productive Tensions in Theory and Practice. Social Politics 12(3): 321-343.

Wee, Bert Van and Banister, David. 2016. How to Write a Literature Review Paper? Transport Reviews 36(2): 278-288.

Wodon, Quentin; Male, Chata; Montenegro, Claudio; Nguyen, Hoa; and Onagoruwa, Adenike. 2018. Educating Girls and Ending Child Marriage: A Priority for Africa. The Cost of Not Educating Girls Notes Series.

Woetzel, Jonathan; Madgavkar, Anu; Ellingrud, Kweilin; Labaye, Eric; Devillard, Sandrine; Kutcher, Eric; Manyika, James; Dobbs, Richard; and Krishnan, Mekala. 2015. The Power of Parity: How Advancing Women's Equality Can Add \$ 12 Trillion to Global Growth. McKinsey Global Institute.

Yumarni, Tri; and Amaratunga, Dilanthi. 2018. Gender Mainstreaming and Sustainable Development Goals: A Systematic Literature Review in Post Disaster Reconstruction Area. In MATEC Web of Conferences

Yunitasari, Riska Yunitasari. 2020. Dinamika Pembaharuan Batas Usia Perkawinan (Analisis Batas Umur Melangsungkan Pernikahan Dalam Hukum Nasional Indonesia). DOKTRINA: JOURNAL OF LAW 3. 1: 9-21. 